This is an electronic reprint of the original article. This reprint may differ from the original in pagination and typographic detail.

Author(s): Onkila, Tiina

Title: $\quad$ Employee Rhetoric in the Acceptance or Rejection of Corporate Environmentalism

Year: $\quad 2017$

Version:

Please cite the original version:

Onkila, T. (2017). Employee Rhetoric in the Acceptance or Rejection of Corporate Environmentalism. Organization and Environment, 30(2), 142-161.

https://doi.org/10.1177/1086026616633270

All material supplied via JYX is protected by copyright and other intellectual property rights, and duplication or sale of all or part of any of the repository collections is not permitted, except that material may be duplicated by you for your research use or educational purposes in electronic or print form. You must obtain permission for any other use. Electronic or print copies may not be offered, whether for sale or otherwise to anyone who is not an authorised user. 


\title{
Employee Rhetoric in the Acceptance or Rejection of Corporate Environmentalism
}

\begin{abstract}
This study explores how employees in a Finnish financial company use rhetorical strategies to accept or reject corporate environmentalism. It is based on a qualitative study in which face-to-face interviews were conducted among 30 employees. The study shows how employees rejected corporate environmentalism by dissociating their employer from polluters or by dissociating environmental values from other values in the financial business. It also shows how they accepted corporate environmentalism by associating it with other business virtues and by associating the employer with polluters. The study identifies rhetorical strategies as means for employees to construct an understanding of corporate environmentalism, and of whether or not it is a part of their organization's responsibilities. The results highlight a need to manage corporate environmentalism processes so that the focus is on finding diverse meanings instead of on promoting a single, organization-wide meaning for corporate environmentalism in a top-down manner.
\end{abstract}

Keywords: Corporate environmentalism, employees, financial company, justification, theory of rhetoric 


\section{Introduction}

The need for corporate environmentalism is nowadays widely recognized (Banerjee, 2003; Flannery, 2005). Many organizations are struggling with their environmentalism while environmental problems continue to worsen (Haigh \& Hoffman, 2014). One reason recognized for this struggle is the attitude toward corporate environmentalism among employees (Hoffman, 2010; Dodge 1997). In this study, I use the concept of corporate environmentalism to study employee views of the phenomenon. By corporate environmentalism I refer to the self-regulated change process of corporate greening (Forbes \& Jermier, 2010; Winn \& Angel, 2000), in which firms integrate environmental concerns into their decision making (Banerjee, 2002), adapt to societal change, and aim at a smaller environmental impact (Wright \& Nyberg, 2012).

Researchers have increasingly stressed that employee views of corporate environmentalism are diversified and not necessarily unanimously supported in organizations (Humphreys \& Brown, 2008; Linnenluecke, Russell \& Griffiths, 2009). This lack of agreement may lead to tensions and contradictions related to corporate environmentalism (Wright \& Nyberg, 2012). These fragmentations and contradictions are often conceptualized as issues that need to be overcome in order to achieve the goal of corporate environmentalism (Linnenluecke et al., 2009). However, the diverse views of employees are often only identified and not explored, meaning their reasons, justifications and consequences are not well understood.

To study the emergence of diverse views on corporate environmentalism, rhetoric offers a useful framework. As Billig (1987) argues, rhetoric is an essential feature in all human language use. It focuses on the persuasive features in language and influences how people arrive at conclusions about issues, such as the acceptance or rejection of corporate environmentalism. Rhetoric gives organizational members the means to see and understand 
issues and make them understandable (Alvesson, 1993). In this way, rhetoric inherently influences corporate practices and decision making. Such an influence means that it is through rhetoric that different meanings for corporate environmentalism, as well as its importance for the organization, are constructed and justified. Those justifications, together with different meanings related to corporate environmentalism, can be studied as rhetorical strategies. By studying the rhetorical strategies employees use, it adds to the understanding of how corporate environmentalism and its importance can be constructed among employees, and generates insight into how its acceptance or rejection may be justified. This understanding helps to consider the corporate environmentalism process from the diverse perspectives of employees and to identify reasons to support or not support corporate environmentalism.

In this study, employees are considered to be rhetors that produce and assign meaning in their language use (Billig, 1987). This means that what employees say and how they say it matter for corporate environmentalism (Green, 2004). I conducted interviews with 30 employees of a Finnish financial company. Based on the research material, this study addresses the following research question: How do employees as rhetors use rhetorical strategies to accept or reject corporate environmentalism? The study identifies four rhetorical strategies as means for employees to construct an understanding of corporate environmentalism, and of whether or not it is a part of their organization's responsibilities. This then influences how corporate environmentalism is approached and practiced among employees (Alvesson, 1993). The results highlight a need to manage corporate environmentalism processes so that the focus is on finding diverse meanings instead of on promoting a single, organization-wide meaning for corporate environmentalism in a topdown manner. 
I first review the existing literature on organizations and the environment that considers previous suggestions of how employees have come to accept or reject corporate environmentalism. Next, the rhetorical approach I applied is presented. The following section introduces the case context, interview material and applied rhetorical analysis. The fourth section lays out the four rhetorical strategies that were identified, and the final section contains discussion, contributions and directions for future research.

\section{Prior Research on Employee Acceptance or Rejection of Corporate Environmentalism}

Although what leads to employee acceptance or rejection of corporate environmentalism has not been directly addressed in previous research, the issue has been indirectly discussed in multiple studies. Our current understanding is based on differing views, from organizationally unified approaches to individually diversified ones. Organizationally unified approaches have suggested that organization-wide acceptance of corporate environmentalism is supported by managerial commitment and organizational values (Aragon-Correa et al., 2004; Del Brio, Fernandez \& Junquera, 2007; Marshall, Cordano and Silverman, 2005; Muller \& Kolk, 2010; Robertson \& Barling, 2012; Wolf, 2012). A number of studies have proposed that the meaning for corporate environmentalism should be created through codes of conduct, communication, employee training, employee volunteering opportunities, and rewarding (Del Brio, Junquera \& Ordiz, 2008; Epstein \& Buhovac, 2010; Haugh \& Talwar, 2010; Mirvis, Googins \& Kinnicut, 2010; Ramus, 2002; 2006; Sammalisto \& Brorson, 2008;

Wolf 2012). Furthermore, it should be supported by information sharing and collaboration (Aragon-Correa, Martin-Tapia \& Hurtado-Torres, 2013). 
Organizationally unified approaches are based on the belief that employee acceptance of corporate environmentalism can be furthered by fostering shared policies (Benn \& Martin, 2010; Haugh \& Talwar, 2010; Hoffman, 2010; Tudor, Barr \& Gilg, 2008) and a shared organizational learning process (Benn and Martin, 2010; Dodge, 1997; Siebenhuner \& Arnold, 2007). This process is seen as requiring employee involvement (Bansal, 2002; Hanna et al., 2000) and congruence between the environmental values of employees and the organization (Collier \& Esteban, 2007; Nilsson, von Borgstede \& Biel, 2004; Ramus \& Killmer, 2007; Russell \& Griffiths, 2008). Positive emotions toward environmentalism and the fear of negative values support acceptance of corporate environmentalism (Fineman, 1996; Russell and Griffiths, 2008). Ambec and Lanoie (2008) also believe that acceptance may be influenced by the pride that employees feel, whereas Carrus, Passafaro and Bonnes (2008) have shown that negative anticipated emotions and past behavior are predictors of a desire to engage in corporate environmentalism. On the other hand, employee rejection of environmentalism is considered to be a result of poorly specified requirements for individual jobs (Ramus \& Killmer, 2007), which can lead to a lack of clear goals and signal uncertainty regarding the benefits of corporate environmentalism.

Instead, individually diversified approaches have showed how employee views of corporate environmentalism are naturally fragmented and how such responsibility is not necessarily unanimously supported in organizations (Humphreys \& Brown, 2008; Linnenluecke et al., 2009). This fragmentation may therefore lead to tensions and contradictions (Wright \& Nyberg, 2012). Environmental values may be seen as contradictory to business values (Hussain, 1999) and they are often associated with complexity and confusing, inconsistent terminology (Jackson \& Seo, 2010). These differences and contradictions are frequently perceived as elements that need to be overcome in order to achieve corporate environmentalism (Harris \& Crane, 2002; Linnenluecke et al., 2009), but 
they are rarely explored further. Instead, the findings generally remain at the level of stating that there are problems related to confusion and tensions, as well as divergent interpretations around corporate environmentalism (Baumgartner, 2009; Harris \& Crane, 2002; HowardGrenvill, 2006; Linnenluecke, 2009).

Overall, the existing body of research on factors that lead to employee acceptance of corporate environmentalism is based on contrasting views that range from organizationally unified to individually diverse. The organizationally unified approaches have strongly suggested that top-down managed processes and shared meanings lead to employee acceptance of corporate environmentalism, but they have not explicitly addressed employee rejection of corporate environmentalism. Instead, individually diversified approaches have identified how tensions, contradictions, and confusing and inconsistent terminology may partly explain the rejection of corporate environmentalism, or at least resistance to it. However, the reasons, justifications and consequences of the individually diversified views have not been further studied. As a methodology, rhetoric enables the exploration of individually diversified views, because it is through an analysis of rhetoric that the focus shifts to the linguistic means by which social meaning and justifications are attached to corporate environmentalism processes. Employees then use these means to construct an understanding of corporate environmentalism that eventually influences how the practice is implemented (Alvesson, 1993). This study's research question uses this perspective of how views are rhetorically constructed among employees to examine the diverse individual views of corporate environmentalism.

\section{A Rhetorical Approach to the Acceptance or Rejection of Corporate}

\section{Environmentalism}


Rhetoric offers a framework for understanding the construction of employees' views on corporate environmentalism and their justifications. It is an essential feature in all human language use. It influences how people arrive at conclusions about issues. It is through rhetoric that actors produce and assign meaning (Billig, 1987). Rhetoric focuses on the persuasive features in language use as well as on the credibility of certain arguments (Billig, 1987; Cheney, Christensen, Conrad \& Lair, 2004; Watson, 1995).

For this study, rhetoric is more than the language of persuasion; it is a means of human understanding and a process for constructing social reality (Putnam, 2004; Watson, 1995). I apply two theories that allow me to analyze the justifications in rhetorical strategies: Perelman and Olbrechts-Tyteca (1969) and Aristotle (1991). Perelman and Olbrechts-Tyteca (1969) base their theory of rhetoric on associations and dissociations between two or more issues. Using liaisons means associative argumentation and creating connections between different phenomena. If arguments are given for the purpose of dissociation, they aim at separating elements that language or recognized traditions have previously tied together, and information becomes structured in a new way. In dissociation, different aspects of phenomena are separated and then reallocated to each other or to some other phenomena. Aristotle (1991) proposes three possible methods for constructing a persuasive claim: ethos, pathos and logos. Ethos draws on the audience's perceptions of ethics and the speaker's ability to present an ethical self. Logos refers to logical argumentation through the words chosen. Pathos refers to the emotions expressed by the speaker (Aristotle, 1991; Cheney et al., 2004). These two theories complement each other in the analysis of justification used in rhetorical strategies. While Perelman and Olbrechts-Tyteca's approach offers a possibility to focus on the relationship between issues, Aristotle's work provides tools for analyzing the characteristics of the message and the speaker. 
In my application of these theories, I follow the assumption that acknowledges the power of rhetoric in constructing corporate environmentalism (Berger \& Luckmann, 1966). I am also in line with the school of new rhetoric that emerged under the influence of the linguistic turn in the 1960s (Billig, 1987; Perelman, 1982; Potter, 1996) and which makes no distinction between rhetoric and reality. Unlike studies of realism, constructionist studies do not aim to reveal social reality, but focus on how people construct versions of social reality in social interaction (Burr, 1995). This focus contrasts with the approach to greenwashing, in which the communication of environmentalism is separated from what is actually being done (Bullis, 1997). However, few studies have acknowledged the power of rhetoric in shaping corporate environmentalism and its features (Grossman, 2000; Livesey, 2002; Vuontisjärvi, 2013; Walton, 2007).

This study frames corporate environmentalism as a rhetorical phenomenon in organizations and employees as rhetors. Employees as rhetors means that what employees say and how they say it matter for corporate environmentalism. Through the use of rhetoric, employees justify diverse views to accept or reject corporate environmentalism. These justifications then influence how corporate environmentalism is approached and practiced among employees (Alvesson, 1993). Understanding the role of rhetoric is important for human resource management in firms because it shows how employees, as well as managers, participate in the definition and process of corporate environmentalism. Rhetoric is one way that views how even conflict with official policies can be spread and justified in organizations. The term rhetorical strategy indicates the ways used to persuade and convince in the claims made as part of language use. In corporate environmentalism, rhetorical strategy refers to the different meanings given to the practice and the different justifications used as a basis for it. In this way the final aim, acceptance or rejection, is constructed. The rhetorical strategy contains the aim as well as the ascribed meanings and justifications. Green (2004) 
presented the idea of the role of rhetoric in the adoption or rejection of an organizational practice. His rhetorical theory of diffusion suggests that the type and sequence of discursive justifications determine the speed and the extent of diffusion that a practice achieves and, ultimately, shape the degree to which the practice becomes taken for granted. When justifications are accepted and taken for granted, a practice becomes institutionalized. Based on this theory, I derived the idea of using language to accept or reject a certain practice in an organization. In this study, that practice is corporate environmentalism.

\section{Research context, material and methods}

\section{Research Context}

The organization being examined is a Finnish financial company that employs about 3,000 people, with operations that cover banking, financing and insurance services. It is a cooperative. The status sets special requirements for them to be transparent and responsible, because the organization is owned by its customers. The same CEO has led the company for more than two decades. During this time, its organizational culture has developed into a stable and leader-centered one. It publishes a responsibility report describing its commitments to environmental, economic and social issues. It participates in multiple projects with responsibility issues, and some of its employees, including the CEO, are active members in Finnish responsibility networks. Communications, actions and functions are all managed by the same unit under the rubric of corporate responsibility, but in practice they are treated separately. For example, in the corporate responsibility report separate sections focus on social, economic and environmental responsibilities, and the responsibility projects address either environmental or social issues. 
The company has had no public conflicts with environmental NGOs or other stakeholders on environmental issues, and it is often considered to be a neutral actor in Finnish society. Two of its offices hold Green Office certificates. It is also increasingly adding paperless services and implementing cooperative projects with environmental NGOs for energy conservation and nature trips. However, the company has not undertaken any groundbreaking environmental measures, and so the case could be described as prototypical (Pratt, 2009). The company was relevant for the study because it operates in the financial industry, where environmental issues are not taken for granted and are, in many cases, even questioned (Weber, Diaz \& Schwegler, 2012; Scholtens, 2011). However, when contacted they showed interest in improving their corporate environmentalism and informed me that the need has been discussed within the organization. I therefore expected rich discussion about corporate environmentalism in this firm.

The interviews were conducted between January and May 2012. Just before this period, the company had faced a challenge: 150 employees were made redundant. This was the first downsizing in the history of the organization. At the same time, the implementation of social and environmental responsibility programs continued. These were communicated to employees through its intranet, printed responsibility leaflets and email. Although it was communicated to all, only a limited number of employees saw concrete changes in their own work. Environmental responsibilities suffered from fragmented approaches to organizational discourse, a problem highlighted especially in public communications. Although commitment to corporate environmentalism was expressed, corporate responsibility reports mentioned that the firm was not a heavy polluter. In this way, corporate environmentalism was limited or even partially rejected. Prior studies have also raised the limitations of corporate environmental responsibilities in the financial sector due to its having little or no 
environmental impact (Roberts, 1991; Weber et al., 2012), a situation which has led to employee difficulties in understanding motivations (Humphreys \& Brown, 2008).

\section{Research Material}

In the organization, 30 people were interviewed, with the interviews ranging in length between 39 and 95 minutes. Men and women from all levels of the organizational hierarchy participated, from the CEO to employees in customer service. Three of the interviewees worked for the corporate responsibility department and were directly responsible for corporate environmentalism. The selection of interviewees was based on purposeful sampling (Patton, 1990; Pratt, 2009) in order to see how employees with different organizational positions and job descriptions in various parts of the organization engage in the fragmented organizational discourse regarding corporate environmentalism. The data creation was part of a larger research project. For the purposes of the project, economic, environmental and social responsibilities were discussed. However, in the public communications, informal discussion, and while doing the interviews, I observed that social and economic responsibilities were more taken for granted than environmental responsibilities were, and, in many cases, these were even questioned.

The interviewees were selected based on criteria suggested by me and in cooperation with a corporate responsibility expert within the organization, who then eventually contacted the interviewees by email. For the trustworthiness of the study, and to remove potential expert bias, I defined what types of employees were to be invited for the interview and no interviews were organized without my acceptance. The final number of interviews representatively covers different divisions of the organization, different units and positions, as well as people who had previously had varying levels of engagement with environmental issues. Roughly categorized into managers, experts and other employees, 10 of the interviewees had some type of a managerial position, 11 of them were experts (experts 
included those with specialist positions to support the work of management and other employees such as investment analysts and communications specialists) and 9 were other employees (employees without a managerial or expert position, such as assistants and customer service persons).

The interviews were conducted in meeting rooms in the company's buildings in four different locations: its headquarters and at three local offices. At these times, only the interviewee and I were present. I entered the field as an external, independent researcher. In the email sent to the interviewees, it was stated that I was not employed by the firm and was there for wider research purposes, not ones sought by the company itself. I did not know any of the interviewees beforehand, and I had never worked for the organization.

To confirm the trustworthiness of the study, I followed the principles of credibility, transferability, dependability and conformability (Guba \& Lincoln, 1986; Patton, 2002; Eriksson \& Kovalainen, 2008). Credibility was confirmed by detailed recording of interviewees' insights and experiences and by using a professional transcriber to transcribe the interviews. For the interviewing technique, this meant no disagreements could be expressed by the interviewer. Credibility was further supported by using quotes from the interviews to show the links between observations and categories. Transferability was confirmed by creating a research setting that could be repeated in other contexts and organizations. This means that, based on the same principles, employees from the three aforementioned categories could be interviewed thematically, and then their answers could be analyzed rhetorically. The results were created on a level that could be tested in other contexts and organizations. However, there is hardly any prior research on employee rhetoric regarding corporate environmentalism with which to compare the results. The rhetorical elements studied are universal, meaning they could be applied in other contexts. Dependability was confirmed by taking detailed notes on the interviewees' jobs, the time and 
place of the interview as well as by clear selection criteria for the interviewees. It was further supported by using a similar structure for each interview, which was then specified with more detailed questions during the interview situation based on the observations made regarding the interviewee's approach and daily activities. This ensured that the same thematic areas were discussed with all the interviewees. To guarantee conformability, I meticulously worked with all the interview transcripts in a qualitative data management program (ATLAS.ti), which also supported tracking of all the coding done during the study. Unfortunately, I had no possibility to use peer debriefing (e.g. Corley \& Gioia, 2004), but I reviewed the coding systems myself on multiple occasions in order to assess the logic of the process. Conformability was further supported by the fact that the researcher had no other interest in or bias toward the organization or topic being studied.

A thematic, open-ended interview guide was used. The interviews focused on the meaning of social, economic and environmental responsibility in the interviewees' daily work. Although only the environmental responsibilities are the focus of this study, this interview structure allowed me to notice how environmental responsibilities were accepted or rejected compared with social and economic responsibilities. The questions had an openended structure. My aim as an interviewer was to have the interviewees talk as openly as possible, in particular comparing and prioritizing different aspects of corporate responsibility. First, the interviewee was asked to provide a job description: what he or she did in the organization, what a typical week at work included, and so forth. Second, views on responsibilities in the company were discussed: how responsibility issues were related to one's own work and how personally important the responsibility issues were. Third, internal corporate responsibility was examined: what was the level of participation in internal responsibility actions and what kinds of positive and negative situations had been experienced. Fourth, external corporate responsibility was considered: what the level of 
participation in external actions was and what recent situations had been positive or negative. Finally, the interview was concluded with a discussion about the importance of responsibility issues in daily decision making and the need for improvements in the future.

\section{Analysis}

In this study, the interview situation is taken as a context in which different perspectives on reality are constructed. The analysis focuses on the language used. However, the language is not considered to be a means for sharing information, because the analysis focuses on speech itself, not on the information. The analysis was approached inductively (Bryman \& Bell, 2007), but rhetorical theories were used to aid the analysis of justifications. Approached inductively, the analysis focused on rhetorical strategies as means of communication and persuasion in the interviews (Bryman \& Bell, 2007). Concerning each rhetorical strategy, the meaning given to corporate environmentalism, the justifications for it and the aim (acceptance or rejection) were analyzed. The rhetorical strategies are not descriptions of what happens in reality if the employees accept or reject corporate environmentalism. Instead, they are descriptions of the rhetorical construction of this phenomenon. The approach was a content analysis, but with rhetorical elements. The phases of analysis are described in Figure 1. In each phase, the analysis first proceeded interview by interview, and then involved looking for similarities and differences between the interviews.

\section{-------INSERT FIGURE 1 ABOUT HERE}

Figure 1. Analysis of rhetorical strategies in the interviews

In the first phase, I read through the material interview by interview and identified environmental sections which I then coded on the basis of the following question: Is corporate environmentalism accepted or rejected as corporate responsibility? The sections of 
texts that I analyzed were long (approximately 10 to 25 sentences). In the second phase, I coded the sections based on the following question: What meaning of corporate environmentalism is the acceptance or rejection related to? This was an essential question for the analysis, since the new rhetorical approach taken assumes that while speaking about corporate environmentalism employees first assign a meaning and then justify it. The different meanings were grouped into initial categories. The identified rejection categories were (a) limited, (b) no significance in individuals’ work and (c) external environmental influence only. The identified acceptance categories were (a) implemented change, (b) need for change, (c) inclusion in one's own work, (d) self-evident, and (e) shared values. In this phase, a couple of sections were reconsidered, especially those in which both positions (acceptance and rejection) were mixed. This led to recoding some sections.

In the third phase, I included my theoretical framework, and applied the ideas of Perelman and Olbrechts-Tyteca (1969) as well as those of Aristotle (1991) on, respectively, association/dissociation and on ethos, pathos and logos. I identified justifications given in relation to each meaning and then compared those with the aforementioned theories to identify the argumentative structure based on the theories. I analyzed each section of text based on the following question: How was acceptance or rejection justified? This process enabled me to identify certain differences and similarities in the texts and their argumentative structures. I then compared the analysis of argumentative structures with the meanings of corporate environmentalism identified in the second phase and noticed that while speaking about the need for change and implementing change, logos-based associative argumentation was used. With the meanings inclusion in own work, self-evident and shared values, ethosand pathos-based associations were used. With the identified meanings external influence only and no significance for individual's work, logos-based dissociations were used, and finally for the meaning of limited environmentalism, ethos-based dissociations were used. 
In the fourth phase, rhetorical strategies emerged from the meanings in the interviews. In those strategies, certain meanings were given to corporate environmentalism and certain justifications were used to accept or reject it. I identified four rhetorical strategies. The strategies were quantified because during the coding in the prior phases I had noticed that the totals in the different categories were surprisingly equally distributed across the data. The total number of coded sections was 173 . Finally, I conducted a more detailed analysis on each strategy. Based on the questions arising from the data I analyzed the following issues: How is corporate environmentalism more extensively framed? What relationship with other responsibilities was constructed? Are there differences depending on the person's job description and position in the company?

\section{Results}

I identified four rhetorical strategies employed in the interviews. These strategies are rhetorical processes that include the justifications used to create a certain view of corporate environmentalism and thus the acceptance or rejection of it. Rejection was based on logosbased dissociation from polluters and on ethos-based dissociation between environmental values and prioritized values in financial business. Acceptance was based on logos-based association with other polluters and ethos- and pathos-based association of environmental values with other virtues in business. Within these strategies, the meaning employees give to environmentalism is related to the justifications for acceptance or rejection of it.

The content of each rhetorical strategy is described in Table 1. The table shows whether each strategy was used for rejecting or accepting corporate environmentalism. It first describes the argumentation process and then the view of corporate environmentalism among other responsibilities. Finally, the number of times that the strategy was used in the original interview sections is included. 


\section{Argumentation on Rejecting Corporate Environmentalism}

\section{Logos-Based Dissociation from Polluters}

Out of 173 sections of discussion, 45 (26\%) fell into this category (Table 1). Logos-based dissociation from polluters results from framing corporate environmentalism as a question of measurable environmental impacts and employing it to show that the employer is a nonpolluter in the societal comparison. The interviewees focused on asserting how little a financial company has to do with the environment. They used logos-based (Aristotle, 1991) arguments to dissociate (Perelman \& Olbrechts-Tyteca, 1969) their employer from polluters and thus distanced corporate environmentalism from other corporate responsibilities. Their logos-based argumentation was that some organizations have fewer environmental impacts than the others do. It clearly emerged that because their employer was a financial company, they viewed it as having no significant environmental impacts.

In this strategy, the interviewees framed corporate environmentalism as a question of physical, measurable environmental impacts. They rhetorically dissociated between actors: a dissociation was created between polluters and non-polluters, and the employing organization was counted as a non-polluter. The logical argumentation (Aristotle, 1991) used draws on perceptions of visible environmental impacts and the question of who has an impact and who does not. The employer is referred to as operating in a less polluting branch of business, because it lacks, for example, smokestacks or factories, while other areas of industry are the ones that have a severe environmental impact. Furthermore, the employer is dissociated from companies with reputations as polluters.

Measuring electricity consumption isn't a thing for us. The consumption of electricity doesn't matter because the lights are the only [thing] and the lights cannot be turned off. Well, okay, we 
do turn off the lights when we exit the office rooms, but then it is not [so meaningful]...In factories it is meaningful.

In addition, irony was used to express the minor environmental impact of the company, and corporate environmentalism was repeatedly referred to in terms of switching the lights off. As one interviewee was describing environmental issues, he laughed and said:

You should ask my boss what he thinks about the idea that I would welcome a customer by suggesting we sit in the dark.

Corporate environmentalism was seen in terms of a narrow view of internal impact. The interviewees typically discussed only a single environmental aspect. The argumentation was also put in quantitative terms to show how minor the environmental impact of the employer was. This follows logical argumentation, in which numbers are used to show the structure of reality (Aristotle, 1991). In the following example, the interviewee describes how "insane” it would be if the company were to focus on saving paper, because in some factories there is more unused paper in storage than they use in one year.

Those $80 \mathrm{~cm}$ wide rolls that are cut like this, so that it's like three rolls of paper. Yeah, over there at the Kirkkoniemi factory there's more of those hanging around in their reject pile.

The interviewees asserted that the environmental impact in their firm was only indirect, and it could be changed only by influencing the action of external actors. Depending on their function in the organization (as well as the external stakeholders they directly interacted with), they named certain external stakeholders whose environmentalism could be improved: for example, employees in customer service described how paperless services should be marketed to customers; employees working with investments focused on descriptions of selecting and auditing investments; and employees involved with purchasing focused on explaining how partners' environmental standards and principles should be checked. Customer service representatives often described how paperless services are marketed to customers. They felt that it is unfortunate, and in some cases even annoying, when they are 
not accepted by customers ("The client just doesn't want it yet”). The interviewees considered the organization to be, unquestionably, a non-polluter. For this reason, employees perceived no need for organizational learning, managerial values or new internal policies.

Interviewer: What should $\mathrm{X}$ (the name of the company) do for environmental issues? Interviewee: Well, be an example. And, of course...Fortunately, in this area of business it's such that we fortunately don’t consume the environment terribly much.

In this strategy, the interviewees explicitly compared corporate environmentalism with other aspects of corporate responsibility. They described social and economic responsibilities as naturally accepted in the organization, while environmental responsibility is not. They reported that environmentalism is not the first thing that is thought of in the organization: "I would see social responsibility as something [more meaningful to us]," and "financial matters are understood.”

\section{Ethos-Based Dissociation Between Environmental Values and Prioritized Values}

Out of 173 sections, 38 (22\%) fell into this category (Table 1). Ethos-based dissociation results from framing corporate environmentalism as a question of value priorities and employing it to show how ethically right it is to focus on prioritized values that do not include corporate environmentalism. The interviewees focused on asserting how values other than environmental ones are more important in a financial company due to ethical reasons. This strategy is thus essentially about relationships between different aspects of responsibility. Employees often responded (when explaining how social, economic and environmental responsibilities are related to their jobs) how either social or economic aspects are the "primary commitment," “deeply thought about,” or “closest to us.”

But if I think about our perspectives—economics, the environment, society—it is economics that is our thing. That is, if we consider that insurance companies are very large investors in Finland. 
Interviewer: Do you see, for instance, that environmental issues have something to do with your work?

Interviewee: Well, we do think more strongly about the other two perspectives.

Rhetorically, rejection drew on the ethos-based (Aristotle, 1991) dissociation (Perelman \& Olbrechts-Tyteca, 1969) of environmental values from other corporate responsibility values. Ethos-based argumentation refers to (Aristotle, 1991) rhetoric that is based on perceptions of the ethically right thing to do in business and dissociated from the more important ends. It draws on conceptions of what is more ethically important than environmental responsibility. There is even a suggestion that it would be unethical to focus on environmental issues while other, more important goals have not yet been reached. A narrow view of environmental impacts was produced, as a range of environmental issues was not identified. Interviewees instead revealed limited views of environmental impacts (e.g., switching the light off).

Based on Aristotle's ethos argumentation, the more important ends described by interviewees included the following issues. First, the primary value of the company is in providing the best possible service for all its customers. This means, for example, having offices around the country. The need for travel then leads to environmental impacts. Second, concerning the relationship between monetary values and environmental values, the conflict between making money and protecting the environment was described-and making money comes first. For example, the lay-offs that the company had recently faced were used as an ethos-based justification. The lay-offs were fresh in employees' minds, because they had been the first ones in the company's history. It was mentioned that the company recently had to make people redundant, and it would not be right, in this situation, to purchase equipment or material that was environmentally friendly but also more expensive. The interviewees often described how the values do not support each other: “It doesn’t go together with business [thinking],” Third, concerning time and environmental values, it was stated that the 
number one priority for them as employees was to do their job, not to read about environmental issues on the company intranet.

In this strategy, the interviewees constructed organizationally conflicting views on value priorities (and uncertainty regarding those). Individual differences in value priorities were brought up. For example, one expert described his discussions with his boss on environmental issues: "We had a slightly different way of thinking about it.” The following extract concerns a situation in which purchasing greener products was considered and the interviewee was responsible for certain purchasing decisions in the organization.

...Sure, you can find those made from recycled materials, but when they are made by 3M, they're always priced in such a way that...We've had a few of them, sure, but there's just not enough of a benefit there when you have the constant pressure to save. You just have to realize that these things don't always go hand in hand.

This strategy highlights the essential role of managers, the commitment and values of whom have been shown in prior literature to be crucial for corporate environmentalism. Managerial action was related to uncertainty regarding the organization's value priorities. That was brought up especially by people in non-managerial positions. Ultimately, it was seen that among employees and experts, corporate environmentalism is primarily the responsibility of managers:

When, in principle, the people are just working here, it is the responsibility of the employers to beat it into their heads.

Because it does not really directly have much to do with my job...Because it does not have to do with our work, but it is other peoples’ decision.

There was also a question regarding "how much the managers value these kinds of things." Surprisingly, employees questioned the car selection of managers (e.g., the type of company car they have chosen and why they did not choose a smaller or hybrid model).

\section{Argumentation for Acceptance of Corporate Environmentalism}




\section{Logos-Based Association with Polluters}

Out of 173 sections, 48 (28\%) fell into this category (Table 1). Logos-based association with polluters results from framing corporate environmentalism as a question of measurable environmental impacts and employing it to show that the employer is one polluter among others in society. While using this strategy the interviewees focused on asserting the financial company's multiplicity of environmental impacts. This was not based on explicit comparisons, but on implicit assumptions, in which corporate environmentalism was unquestionably included among corporate responsibilities. In this strategy, the interviewees framed corporate environmentalism as a question of multiple, measurable environmental impacts that requires change in corporate practices. They either demonstrated implemented changes or the need to implement more changes. Corporate environmentalism was still constructed as something that has not been taken for granted or institutionalized (Green, 2004), because it requires multiple supportive arguments, although environmental impacts are taken to be self-evident.

The employees associated (Perelman \& Olbrechts-Tyteca, 1969) the organization as a polluter by means of logos-based arguments (Aristotle, 1991). In this argumentation, organization has multiple environmental impacts and it should improve in those areas. The interviewees drew on a range of environmental impacts by listing them, with the impacts seen as being self-evident and not questioned. The firm is associated with other polluters in society.

Logos-based association was based on the identification of changes related to the environmental impacts. Changes already implemented appeared in many cases to be a response to inquiries about environmental issues, which result in savings of environmental resources but in some cases also money. Unlike with rejection strategies, in which often only a single environmental aspect was mentioned, change was related to a gamut of 
environmental impacts. Interviewees also talked about switching the lights off, but the acceptance of corporate environmentalism was additionally related to other energy-saving measures, paperless services, transportation and work trips, purchasing, different kinds of events for environmental consciousness, the Green Office system, having local food served at customer events, recycling, investment decisions, less printed material and so forth. In these ways, environmentalism was conceptualized as something very concrete in the organization. In many cases, the employees were even able to show quantitative evidence of how, for example, consumption of paper or energy had decreased in their division.

These descriptions and enumerations were closely related to the employees' respective daily work routines, and they varied depending on the part of the organization in which they worked. However, each interviewee described a range of environmental impacts related directly to their work (along with how that work should be changed and how it has been improved). This strategy was used more by experts and other employees than managers. In different parts of organizations, the lists of changes and need for changes vary (e.g., in customer service the focus is on printing and energy conservation). The following example provides a list of changes that have already been implemented:

Well, anything that's really practical. Practical in the sense that we have in a way a kind of motto or slogan of "act like you would act at home.” Things like are the lights still on in your office when you leave. When you are the last one in the building, before you leave look around and check that all the lights are out, the coffee maker isn't left on unnecessarily. And about commuting, it's not that we're talking about, but business trips. That would be going too far. Of course when it's brought up, sure, we can think if we have to drive to work. But above all, realize when you're going to the main office, use the remote connections. It's really grown a lot. Take the train instead of your car, carpooling. Then there's food service, where the starting points are no disposable plates and utensils, but also local food. For a lot of our investor events, we've made sure the food is from the local region and preferably organic.

The following extract provides an example of how the need for further change was identified. 
We've got a lot to work on in that area. In a bank it's always so that when a customer's signature is needed, a lot of paper gets used. Now we're going in the direction that we try to get as much done electronically as we can. But then there are the special processes where paper is needed so that you can move forward. But then there are people’s ways of working, like does everything need to be printed. And with this program it tries to tell people, but maybe it requires that it's said for a longer time.

The interviewees described how corporate environmentalism is something to be naturally taken into account among other corporate responsibilities, and thus associated it with other responsibilities in business. It was described how environmental improvements are made in the organization, independent from challenges (e.g., downsizing). This is how an expert (working in IT management) responded when asked about actions taken for corporate environmentalism:

Well, we have had campaigns for instance. Now we are kind of living through a bit of an odd phase at the moment, that now we have the negotiations about staff reduction going on and all, so that we are sharing the scraps...But we have had such information campaigns. And at one point, the departments started strongly themselves, something which we in IT management were promoting, that the departments should be monitoring from the printers how much they are printing and setting goals for themselves about how much they should reduce.

The interviewees drew on an idea of sharing, which has been mentioned in the literature as shared values and cultures, and also thus associated corporate environmentalism with their daily routines, as happens in any environmentally responsible firm. They show how corporate environmentalism has been concretely shared in the organization, most often with their immediate colleagues. They described, for example, the following improvements: "The staff is talking with each other about this kind [of stuff]" and "There has been talk about cutting down [the use of] paper and this kind of thing,” as well as certain improvements (e.g., energy and waste separation) that make it so "everybody could make a difference.”

Ethos- and Pathos-Based Association with Business Virtues 
Out of the 173 studied sections, 42 (24\%) fell into this category (Table 1). Ethos- and pathosbased association with business virtues results from framing corporate environmentalism as a value-based question and employing them to show the importance of environmental values among other business values. The interviewees focused on asserting that corporate environmentalism is one of many business values. Employees arrived at acceptance by associating (Perelman \& Olbrechts-Tyteca, 1969) values based on ethos and pathos arguments (Aristotle, 1991), which show the importance of virtual values (environmentalism being one of those) for the organization. Corporate environmentalism was conceptualized in terms of a multiplicity of environmental impacts that are linked with either shared values or one's own work.

The interviewees drew on ethos (Aristotle, 1991) rhetoric, which is based on perceptions of ethical actions in business, and corporate environmentalism was then associated as one of those actions (Perelman \& Olbrechts-Tyteca, 1969). Pathos (Aristotle, 1991) rhetoric was also employed by interviewees, even including emotional descriptions of the historical roots of the company and those roots' implications for current actions. These values were constructed as being shared throughout the organization and the employer was described as the source of shared organizational values on corporate environmentalism. Value congruencies in this strategy were given two meanings: as an association between organizational and environmental values and as an association between an individual's work and environmental values. First, the interviewees expressed congruence between shared organizational values and environmental values. Environmental values were constructed among other basic organizational values, which were derived, for instance, from the history of the organization, such as the company's so-called green glasses. It was also mentioned that environmental values are congruent with the rest of the company's basic values through, for example, financial savings: 
Interviewer: That's right. Yeah. Do you think there's a meaning for (firm X) to have this kind of responsible business operation? Interviewee: Well, sure, I see that it fits (firm X's) brand pretty well. Interviewer: OK. Why is that? Interviewee: Well, as an insurance company and with our products and with what we insure, we have a lot of forest, farms and other Finnish stuff that is connected to nature. Interviewer: I see. Interviewee: So, yeah, in that way, I’d say that greenness fits well.

Second, the employees expressed association between their own work and environmental values. This is based on how they identify multiple types of environmental impact related to their daily working routines, such as energy conservation, going paperless and less printing, and not just simply switching the lights off. However, the congruence with one's own work did not create any willingness or need to innovate. Instead, it was related to following organizational rules and instructions on saving energy and recycling waste, for example, and actual environmental responsibilities that an individual's work demands, such as in purchasing decisions:

Above all it's definitely most clearly visible in these kinds of issues, our everyday practices.

In this strategy, the company is constructed as a frame for shared environmental responsibility in the organization. The identification of a range of environmental impacts is not questioned, but taken for granted, and corporate environmentalism becomes constructed as institutionalized or taken for granted in the organization (see Green, 2004):

I don't remember that kind of questioning, that someone would have questioned that this is all in vain or something like that.

There were no clear differences based on division or position in the organization, but the strategy was employed by people with different positions and from different departments. It was frequently mentioned by different people how the organization's task is to spread responsibility in society. One interviewee (in a non-managerial position) said when talking about corporate environmentalism: "We want to be a value promoter in society as well and initiate discussion about the theme of responsibility." Previous literature has highlighted the importance of both managerial and individual values for corporate environmentalism. This 
rhetorical strategy fit the approach in terms of both organizationally shared values and individual ones, but it did not straightforwardly highlight the values of managers. Instead, it was something shared.

\section{Discussion and Conclusions}

\section{Discussion}

The study identified the rhetorical strategies through which diverse views on corporate environmentalism were constructed among employees in a Finnish financial firm. Rejection was based on dissociation of the employer from polluters and dissociation of environmental values from prioritized values in business. Acceptance was based on associating corporate environmentalism with other business virtues and by associating the employer with polluters. In the identified rhetorical strategies, corporate environmentalism was framed either as a value question or as one based on environmental impacts. Both frames served to reject as well as to accept corporate environmentalism. Each interviewee employed more than one rhetorical strategy in the interview, sometimes in contradictory ways. For example, an interviewee might express rejection in the first part of the interview but signal acceptance in the second part. Although each employee used both acceptance and rejection strategies, some interviewees naturally used acceptance strategies more frequently. This tendency was not due to the position of the employee, nor to the division in the organization. On the contrary, those employees could be found throughout the organization. However, people with different positions in the organization did concretize corporate environmentalism in different ways. This means that their understandings of corporate environmentalism were tied to their daily working routines and to what they experienced regarding environmental issues in their daily working environments. Thus the arguments had little to do with the core business of the company, such as investment decisions, as only a couple of interviewees dealt with 
investments. If the investment perspective had been brought up in interview questions, it might have increased interviewees' understanding regarding the multiplicity of environmental impacts, and might then have increased the use of acceptance strategies. Furthermore, employees with a managerial position seemed to use fewer ethos-based dissociations. Notably, pathos-based justifications were not used for rejection at all. This result indicates the emotionally laden nature of corporate environmentalism. Thinking of the practice emotionally seems to be a basis for acceptance only, while ethos and logos may also be a basis for rejection.

Based on this study, it could be hypothesized that when corporate environmentalism is justified associatively with the daily routines of employees, they are likely to accept it. If the justification is dissociative, they are likely to reject it. However, the study is limited in many ways that need to be addressed in future research. In this study, only 30 employees were interviewed in an organization with 3,000 employees. It provided a perspective on the rhetoric surrounding corporate environmentalism in a single organization only. Furthermore, the study focused on only a single stakeholder group of corporate environmentalismemployees. The process, however, is influenced by a wider range of stakeholders. The approach taken in this study was inherently contextual, and the results are not to be directly generalized.

\section{Contributions}

The study contributes to the management literature on organizations and the environment by increasing the understanding regarding the multiplicity of meanings for corporate environmentalism and the justifications that influence the corporate environmentalism process among employees. It offers an understanding of how employees use rhetorical strategies to construct diverse views of corporate environmentalism and how the 
constructions are then justified. These rhetorical strategies are means for employees to construct an understanding of corporate environmentalism, and of whether or not it is a part of their organizations' responsibilities. This process then influences how corporate environmentalism is approached and practiced among employees (Alvesson, 1993).

Environmental issues in business are marked by complexity. Not only are they assigned various meanings, but the emergence of diverse views does not necessarily result from different justifications. In fact, the same justifications, such as ethical priorities, can be used for different ends. In this case of a Finnish financial company, they were used to either reject or accept corporate environmentalism. The meanings assigned to corporate environmentalism therefore varied greatly depending not only on the speaker and the situation, but also on the issues that were either associated or dissociated with it. These naturally diverse meanings and justifications could still lead to reinforcing acceptance, and so they are not necessarily something that needs to be overcome to implement corporate environmentalism (see Harris \& Crane, 2002; Linnenluecke et al., 2009).

This diversity offers new avenues for research on the environment and organizations. In other words, the complexity of corporate environmentalism cannot be addressed by simply fostering shared policies (see Benn \& Martin, 2010; Haugh \& Talwar, 2010; Hoffman, 2010; Tudor, Barr \& Gilg, 2008). Instead, it requires a focus on the multiplicity of daily meanings employees assign to corporate environmentalism. One single definition for corporate environmentalism and its justifications - one that each employee could agree on without question-might be difficult to find in an organization. Excluding the naturally diversified meanings from the corporate environmentalism processes might make it more difficult to influence the mindsets of all employees. Finally, because all of the employees used both acceptance and rejection strategies, they could not be categorized into green and non-green employees (see Norton, Parker, Zacher \& Ashkanasy, 2015), but they were all more or less in 
a grey, in-between area. Therefore, instead of categorizing employees, there should be categories for the arguments that influence the process in organizations in different situations. Furthermore, based on this study, it seems that the meanings employees assign to corporate environmentalism and their justifications are based on each individual's daily job. This finding is a practical contribution of the study, highlighting a need for managing corporate environmentalism processes in a way in which the focus is on finding the diverse meanings instead of on promoting a single organization-wide meaning for corporate environmentalism. This implies that managers should examine their top-down methods of managing corporate environmentalism. They should rather focus on finding the different daily meanings and exploring the justifications for and against corporate environmentalism, thereby leaving room for employees to find meanings that associate with individual roles, the environmental impacts experienced and value priorities. This conclusion is somewhat in conflict with previous research that has been dominated by calls for integrated, managerially led change processes for corporate environmentalism (see Baumgartner, 2009; Del Brio, Fernandez \& Junquera, 2007; Ramus, 2002; Robertson \& Barling, 2012; Wolf, 2012).

\section{Future Research Directions}

Because the study addressed employee rhetoric in an organization, that naturally labels the results of the study. Rhetorical features of corporate environmentalism need to be studied more extensively in a range of companies across various industries in order to identify the typical features and differences between them, especially those between industries with less visible environmental impacts and those with heavier impacts. Because corporate environmentalism is influenced by a wide range of stakeholders, further understanding of how the process is shaped by rhetoric requires that studies should be carried out on how other groups of stakeholders use rhetoric related to corporate environmentalism in various 
situations, including public communications, documents and interviews. This perspective would yield understanding of different groups as rhetors (e.g., specific groups of employees or influential stakeholder groups). The approach taken in this study was contextual, so there is also a need for more quantitative approaches to employee perceptions of the corporate environmentalism process. In particular, employee perspectives on the acceptance or rejection of corporate environmentalism require further research in terms of how employees experience what is already prioritized in the organization and what should be prioritized.

\section{References}

Alvesson, M. (1993). Organisations as rhetoric: knowledge-intensive firms and struggle with ambiguity. Journal of management studies, 30, 997-1015

Ambec, S. \& Lanoie, P. (2008). Does it pay to be green? A systematic overview. Academy of management perspectives, 22, 45-62.

Aragon-Correa, J., Martin-Tapia, I. \& Hurtado-Torres, N. (2013). Proactive environmental strategies and employee inclusion: the positive effect of information sharing and promoting collaboration and the influence of uncertainty. Organization \& environment, 26, 139-161.

Aragon-Correa, J., Matias-Reche, F. \& Senise-Barrio, M. (2004). Managerial discretion and corporate commitment to the natural environment. Journal of Business research, 57, 964-975.

Aristotle. (1991). The Art of Rhetoric. New York: Penguin books.

Banerjee, B. (2002). Corporate environmentalism. The construct and its measurement. Journal of business research, 55, 177-191.

Banerjee, B., Iyer, E. \& Kashyap, R. (2003). Corporate environmentalism: antecedents and influence of industry type. Journal of Marketing, 67, 106-122. 
Bansal, P. (2002). The corporate challenges of sustainable development. Academy of management executive, 16, 122-131.

Baumgartner, R. (2009). Organizational culture and Leadership: preconditions for the development of a sustainable corporation. Sustainable development, 17, 102-113.

Benn, M. \& Martin, A. (2010). Learning and change for sustainability reconsidered: a role for boundary objects. Academy of management learning \& education, 9, 397-412.

Berger, P.L. \& Luckmann, T. (1966). Social construction of reality. A treatise in thesociology of knowledge. New York: Garden City.

Billig, M. (1987). Arguing and thinking. A rhetorical approach to social psychology. Cambridge: University Press.

Bullis, C. (1997). Business communication and the natural environment: using traditional and contemporary perspectives to understand the connections. The journal of business communication, 34, 455-477.

Burr, V. (1995). An introduction to social constructionism. London: Routledge.Bryman, A. \& Bell, E. (2007). Business research methods. Oxford: Oxford University Press.

Carrus, G., Passafaro, P., \& Bonnes, M. (2008). Emotions, habits and rational choices in ecological behaviours: The case of recycling and use of public transportation. Journal of environmental psychology, 28, 51-62.

Cheney, G., Christensen, L.T., Conrad, C. \& Lair, D.J. (2004). Corporate rhetoric as organizational discourse. In Grant, D., Hardy, C., Oswick, C. and Putnam, L. (Eds). The SAGE handbook of organizational discourse. London: Sage publications ltd.

Collier J. \& Esteban R. (2007). Corporate social responsibility and employee commitment. Business ethics: a European review, 16, 19-33.

Corley, K. \& Gioia, D. (2004). Identity ambiguity and change in wake of a corporate spin off. Administrative science quarterly, 49, 173-208. 
Del Brio, J., Fernandez, E. \& Junquera, B. 2007. Management and employee involvement in achieving an environmental action-based competitive advantage: an empirical study. International journal of human resource management, 18, 491-522.

Del Brio, J.A., Junquera, B., \& Ordiz, M. (2008). Human resources inadvanced environmental approaches - a case analysis. International Journal of ProductionResearch, 46, 6029-6053.

Dodge, J. (1997). Reassessing culture and strategy:Environmental improvement, structure, leadership and control. In Welford, R.(Ed.) Corporate environmental management and. 2. Culture and organizations.London: Earthscan.

Eriksson, P. \& Kovalainen, A. (2008). Qualitative methods in business research. Great Britain: SAGE

Epstein, M.J. \& Buhovac, A.R. (2010). Solving the sustainability implementation challenge. Organizational dynamics, 39, 306-315.

Fineman, S. (1996). Emotional subtexts in Corporate Greening. Organization studies, 17, 479-500.

Flannery, T. (2005). The Weather Makers: The History and Future Impact of Climate Change. Melbourne: Text publishing.

Forbes, L. \& Jermier, J. (2010). The new corporate environmentalism and the ecology of commerce. Organization and Environment, 23, 465-481.

Green, S.E. (2004). A rhetorical theory of diffusion. Academy of Management Review, 29, 653-669.

Grossman, P. (2000). Corporate interest and trade liberalization: the north American free trade agreement and environmental protection. Organization and Environment, 13, 61-85. 
Hanna, M.D., Rocky Newman, W., \& Johnson, P. (2000). Linking operational and environmental improvement through employee involvement. International Journal of operations and Production Management, 20, 148-165.

Harris, L. \& Crane, A. (2002). The greening of organizational culture. Management views on the depth, degree and diffusion of change. Journal of organizational change management, 15, 214-234.

Haigh, N. \& Hoffman, A. 2014. The New Heretics: hydrid organizations and the challenges they present to corporate sustainability. Organization \& Environment, 27, 223241.

Haugh, N. \& Talwar, A. (2010). How do corporations embed sustainability across the organization? Academy of management learning \& education, 9, 384-396.

Hoffman, A. (2010). Climate change as a cultural and behavioral issue: addressing barriers and implementing solutions. Organizational dynamics, 39, 295-305.

Howard-Grenvill, J. (2006). Inside the "black box". How organizational culture and subcultures inform interpretations and actions on environmental issues. Organization \& Environment, 19, 46-73.

Humphreys, M. \& Brown, A.D. (2008). An analysis of corporate social responsibility at Credit line: a narrative approach. Journal of Business ethics, 80, 403-418.

Hussain, S. (1999). The ethics of "going green”: the corporate social responsibility debate. Business strategy and the environment, 8, 203-210.

Lincoln, Y. \& Guba, E. (1985). Naturalistic Inquiry. Newbury Park: Sage Publications.

Linnenluecke, M., Russell, S., \& Griffiths, A. (2009). Subcultures and sustainability practices: the impact on understanding corporate sustainability. Business strategy and the environment, $18,432-452$. 
Livesey, S.M. (2002). Global warming wars: rhetorical and discourse analytic approaches to ExxonMobil’s Corporate Public Discourse. The Journal of Business Communication, 39, 117-148.

Marshall, R.S., Cordano, M., \& Silverman, M. (2005). Exploring individual and institutional drivers of proactive environmentalism in the US wine industry. Business strategy and the environment, 14, 92-109.

Mirvis, P., Googins, B., \& Kinnicut, S. (2010). Vision, mission and values: Guideposts to sustainability. Organizational dynamic, 39, 316-324.

Muller, A. \& Kolk, A. (2010). Extrinsic and intrinsic drivers of corporate social performance: evidence from foreign and domestic firms in Mexico. Journal of Management studies, 47, 1-26.

Nilsson, A., von Borgstede, C. \& Biel, A. (2004). Willingness to accept climate change strategies: the effect of values and norms. Journal of environmental psychology, 24, 267-277.

Norton,T., Parker, S., Zacher, H. \& Ashkanasy, N. 2015. Employee green behavior: A theoretical framework, multilevel review, and future research agenda. Organization \& Environment 28, 103-125.

Patton, M. (2002). Qualitative research \& evaluation methods. United states of America: Sage publications inc.

Perelman, C. \& Olbrechts-Tyteca, L. (1969). The new rhetoric: A treatise on argumentation. Notre Dame: University of Notre Dame Press.

Perelman, C. (1982). The Realm of Rhetoric. London: Notre Dame.

Potter, J. (1996). Representing reality: discourse, rhetoric and social construction. London: Sage publications ltd. 
Putnam, L. (2004). Dialectical and rhetorical tropes in negotiations. Organization studies, 25, $35-53$.

Ramus, C.A. and Killmer, A.B.C. (2007). Corporate greening through prosocial extrarole behaviours - A conceptual framework for employee motivation. Business Strategy and the Environment, 16, 554-570.

Ramus, C. (2002). Encouraging innovative environmental actions: what companies and managers must do. Journal of world business, 37, 151-164.

Robertson, J. \& Barling, J. (2012). Greening organizations through leaders' influence on employees pro-environmental behaviors. Journal of organizational behavior DOI: 10.1002/job.1820.

Russell, S. \& Griffiths, A. (2008). The role of emotions in driving workplace proenvironmental behaviors. In Zerbe, W., Hartel, C. \& Ashkany, N. (Eds.) ～Research on Emotion in Organizations. Volume 4: Emotions, Ethics and DecisionMaking. Emerald.

Sammalisto, K. \& Brorson, T. (2008). Training and communication in the implementation of environmental management systems (ISO 14001): a case study at the university of Gävle, Sweden. Journal of Cleaner Production, 16, 299-309.

Siebenhuner, B. and Arnold, M. (2007). Organizational learning to manage sustainable development. Business strategy and the environment, 16, 339-353.

Scholtens, B.(2011). Corporate social responsibility in the international insurance industry. Sustainable development, 19, 143-156.

Tudor, T., Barr, S. \& Gilg, A. (2008). A novel conceptual framework for examining environmental behavior in large organizations. A case study of the Cornwall National Health Service (NHS) in United Kingdom. Environment and behavior, 40, 426-450. 
Vuontisjärvi, T.( 2013). Argumentation and socially questionable business practices: The case of employee downsizing in corporate annual reports. Scandinavian journal of management (Article in press).

Watson, T.J. (1995). Rhetoric, discourse and argument in organisational sense making:a reflexive tale. Organisation studies,16, 805-821.

Walton, S. (2007). Site the mine in our backyard! Discursive strategies of community stakeholders in an environmental conflict in New Zealand. Organization \& Environment, 20, 177-203.

Weber, O., Diaz, M. and Schwegler, R. (2012). Corporate social responsibility of the financial sector - strengths, weaknesses and the impact on sustainable development. Sustainable development DOI: 10.1002/sd.1543.

Winn, M. \& Angell, L. (2000). Towards a process model of corporate greening. Organization studies, 21, 1119-1147.

Wolf, J. (2012). Improving sustainable development of firms: the role of employees. Business Strategy and the Environment. DOI: 10.1002/bse.1731.

Wright, C. \& Nyberg, D. (2012). Working with passion: emotionology, corporate environmentalism and climate change. Human relations, 65, 1561-1587. 
Figure 1. Analysis of rhetorical strategies in the interviews

$\begin{array}{lll}1 \text { ACCEPTANCE OR REJECTION } & \text { 2 MEANING OF CORPORATE } & \text { 3 ARGUMENTATIVE } \\ & \text { ENVIRONMENTALISM } & \text { STRUCTURE }\end{array}$

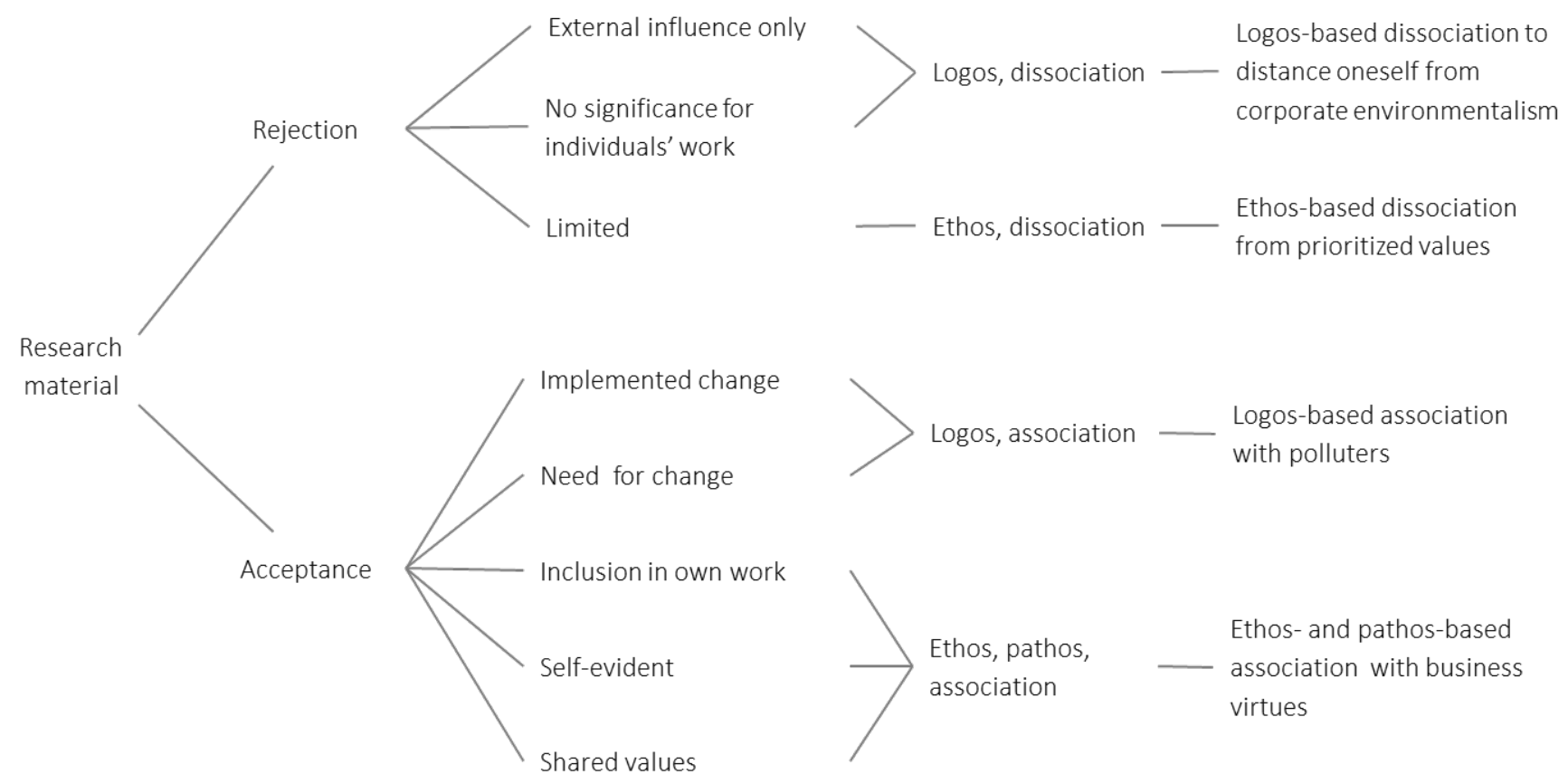


Table 1: Rhetorical strategies for rejecting or accepting corporate environmentalism

\begin{tabular}{|c|c|c|c|c|}
\hline Rhetorical strategy & Argumentation process & $\begin{array}{l}\text { View on corporate } \\
\text { environmentalism vs. other } \\
\text { responsibilities }\end{array}$ & Quantity & $\%$ \\
\hline $\begin{array}{l}\text { Logos-based } \\
\text { dissociation to } \\
\text { distance corporate } \\
\text { environmentalism }\end{array}$ & $\begin{array}{l}\text { Logos-based dissociation from polluters results from } \\
\text { framing corporate environmentalism as a question of } \\
\text { measurable environmental impacts and employing it to } \\
\text { show that the employer is a non-polluter in the societal } \\
\text { comparison. }\end{array}$ & $\begin{array}{l}\text { Narrow view of environmental } \\
\text { impacts: social and economic } \\
\text { responsibilities are naturally } \\
\text { accepted }\end{array}$ & 45 & $26 \%$ \\
\hline $\begin{array}{l}\text { Ethos-based } \\
\text { dissociation between } \\
\text { environmental values } \\
\text { and prioritized values }\end{array}$ & $\begin{array}{l}\text { Ethos-based dissociation results from framing } \\
\text { corporate environmentalism as a question of value } \\
\text { priorities and employing it to show how it is ethically } \\
\text { right to focus on prioritized values that do not include } \\
\text { corporate environmentalism. }\end{array}$ & $\begin{array}{l}\text { Narrow view of environmental } \\
\text { impacts: social and economic } \\
\text { responsibilities prioritized }\end{array}$ & 38 & $22 \%$ \\
\hline $\begin{array}{l}\text { Logos-based } \\
\text { association with } \\
\text { polluters }\end{array}$ & $\begin{array}{l}\text { Logos-based association with polluters results from } \\
\text { framing corporate environmentalism as a question of } \\
\text { measurable environmental impacts and employing it to } \\
\text { show that the employer is one polluter among others in } \\
\text { society. }\end{array}$ & $\begin{array}{l}\text { Broad view of environmental } \\
\text { impacts: Natural among other } \\
\text { responsibilities }\end{array}$ & 48 & $28 \%$ \\
\hline $\begin{array}{l}\text { Ethos- and pathos- } \\
\text { based association } \\
\text { with business virtues }\end{array}$ & $\begin{array}{l}\text { Ethos- and pathos-based association with business } \\
\text { virtues results from framing corporate } \\
\text { environmentalism as value-based question and } \\
\text { employing them to show the importance of } \\
\text { environmental values among other business virtues. }\end{array}$ & $\begin{array}{l}\text { Broad view environmental } \\
\text { impacts: A virtue among other } \\
\text { responsibilities }\end{array}$ & 42 & $24 \%$ \\
\hline & & & Total 173 & $100 \%$ \\
\hline
\end{tabular}

